KaTARZYNA LASKOWSKA

Uniwersytet w Białymstoku

\title{
PRZESTĘPSTWO HANDLU LUDŹMI W ROSJI - ASPEKTY PRAWNE
}

\section{WPROWADZENIE}

Handel ludźmi stanowi poważne przestępstwo o charakterze międzynarodowym, jednakże przez wiele lat nie występowało ani w radzieckim, ani w rosyjskim ustawodawstwie. Pomimo ratyfikacji przez ZSRR w 1954 r. Konwencji w sprawie zwalczania handlu ludźmi i eksploatacji prostytucji z 2 grudnia 1949 r. takiego czynu w tym państwie nie inkryminowano.

Dopiero w kodeksie karnym Federacji Rosyjskiej z 1996 r. ${ }^{1}$ (k.k. FR) zawarto przestępstwo handlu dziećmi (art. 152). Następnie po ratyfikacji Protokołu o zapobieganiu, zwalczaniu oraz karaniu za handel ludźmi, w szczególności kobietami i dziećmi, uzupełniającego Konwencję Narodów Zjednoczonych przeciwko międzynarodowej przestępczości zorganizowanej, przyjętego przez Zgromadzenie Ogólne Narodów Zjednoczonych 15 listopada 2000 r. do kodeksu karnego FR

1 Federalnyj zakon ot 13 ijunia 1996 g. Nr 63 FZ „Ugołownyj kodeks Rossijskoj Federaciji”, http://www.consultant.ru/document/cons_doc_LAW_10699/ (dostęp: 21 października 2018 r.). 
wprowadzono przestępstwo handlu ludźmi (art. 12711). Nastąpiło to w 2003 r. ${ }^{2}$ W związku z tym art. 152 k.k. FR utracił moc. Czyn z art. $127^{1}$ zamieszczono w części 17 kodeksu karnego FR „Przestępstwa przeciwko wolności, czci i godności jednostki”.

Ochronę prawną człowieka przed handlem ludźmi przewiduje też Konstytucja Federacji Rosyjskiej z 1993 r. ${ }^{3}$ Artykuł 22 gwarantuje każdemu prawo do wolności i nietykalności osobistej, a art. 27 zabezpiecza każdemu legalnie przebywającemu na terytorium Federacji Rosyjskiej prawo do swobodnego poruszania się, wyboru miejsca pobytu i zamieszkania. Ponadto, pozwala każdemu na swobodne opuszczanie granic Federacji Rosyjskiej i swobodny do niej powrót.

W ten sposób uznano, że transakcje, których przedmiotem są ludzie, traktowani jak towar, są sprzeczne z prawem międzynarodowym i rosyjskim ${ }^{4}$.

Celem niniejszego opracowania jest ukazanie regulacji prawnej przestępstwa handlu ludźmi w świetle rosyjskiego kodeksu karnego. Ze względu na jej rozbudowany zakres omawiany czyn zostanie przeanalizowany według określonego schematu. Trzy części opracowania będą zawierały szczegółowe rozważania dotyczące strony przedmiotowej, a ostatnia uwzględni pozostałe znamiona tego czynu.

2. TyP PODSTAWOWY HANDLU LUdŹMI - ART. $127^{1}$ PKT 1 K.K. FR

Na podstawie art. $127^{1}$ pkt 1 k.k. FR karalne jest: „Kupno-sprzedaż człowieka, inne transakcje dotyczące człowieka, a także dokonywane w celu jego eksploatacji werbowanie, przewożenie, przekazywanie, przechowywanie lub przyjęcie".

2 Federalnyj zakon ot 8 dekabria 2003 g. Nr 162 „O wniesienii izmienienij i dopołnienij w Ugołownyj kodeks Rossijskoj Federaciji”, http://base.garant.ru/12133485/ (dostęp: 21 października 2018 r.).

3 Konstitucija Rossijskoj Federaciji, priniata 12 dekabria 1993 g., http://www. constitution.ru/ (dostęp: 21 października 2018 r.).

4 W.A. Kazakowa, A.S. Michlin, Art. 127'1, [w:] Kommentarij k Ugołownomu kodeksu Rossijskoj Federaciji, red. W.I. Radczenko, Moskwa 2009, s. 204. 
Zacytowany przepis określa kilka zestawów ustawowych znamion strony przedmiotowej. Dokonanie przestępstwa stanowi wypełnienie chociażby jednego ${ }^{5}$. Formy handlu ludźmi zostały w nim wymienione w sposób wyczerpujący. Zostaną omówione poniżej.

Kupno-sprzedaż człowieka polega na zachowaniu dwóch osób: sprzedającej i kupującej. Pierwsza przekazuje drugiej za opłatą jednego człowieka lub kilkoro ludzi, a druga - otrzymuje go lub ich, przekazując za to pieniądze, mienie lub prawo majątkowe ${ }^{6}$. Zatem kupno obejmuje przejęcie człowieka za określoną zapłatę, a sprzedaż - przekazanie/ oddanie człowieka innej osobie ${ }^{7}$. Jest to transakcja o charakterze materialnym ${ }^{8}$, stanowiąca realizację swoistej umowy między kupującym i sprzedającym o przekazaniu i przyjęciu za określoną zapłatę człowieka jak rzecz ${ }^{9}$ „ „Żywy towar” można kupić różnorodnie: drogą przekazania za dług ${ }^{10}$, w celu bezpośredniego wykorzystania go, jak również do dalszej odsprzedaży w celu osiągnięcia korzyści ${ }^{11}$. Należy podkreślić, że w świetle prawa taka umowa nie ma mocy prawnej ${ }^{12}$; dla bytu prze-

5 O.S. Kapinus, Priestuplienija protiw swobody, czesti i dostoinstwa licznosti, [w:] Ugołownoje prawo Rossiji. Osobiennaja czast', red. I.E. ZwIERCZAKowskiJ, Moskwa 2010, s. 107.

6 Ibidem, s. 107.

7 W.P. Stiepalin, Priestuplienija protiw swobody, czesti $i$ dostoinstwa licznosti, [w:] Kommentarij k Ugołownomu kodeksu Rossijskoj Federaciji, red. A.I. Rarog, Moskwa 2012, s. 266.

8 N.I. Priachina, Priestuplienija protiw swobody, czesti i dostoinstwa licznosti, [w:] Ugołowoje prawo Rossiji. Osobiennaja czast', red. N.M. Kropacziow, B.W. WoŁŻEnkin, A.I. BojCow, Sankt Petersburg 2010, s. 287. Umowa o charakterze realnym stanowi odpowiednik występującej w polskim prawie umowy realnej obejmującej zarówno złożenie oświadczenia, jak i wydanie przedmiotu.

W.W. Swierczkow, Priestuplienija protiw swobody, czesti i dostoinstwa licznosti, [w:] Kommentarij k Ugołownomu kodeksu Rossijskoj Federaciji, red. W.T. Tomin, W.W. Swierczkow, Moskwa 2010, s. 414.

10 M.P. Żurawliow, Priestuplienija protiw swobody, czesti i dostoinstwa licznosti, [w:] Ugołowoje prawo Rossiji. Czasti obszczaja i osobiennaja, red. A.I. Rarog, Moskwa 2010, s. 326.

11 A.I. Rarog, Priestuplienija protiw swobody, czesti i dostoinstwa licznosti, [w:] Ugołowoje prawo Rossiji. Osobiennaja czast', red. A.I. Rarog, Moskwa 2009, s. 88.

12 W.W. SWIERCzKow, op. cit., s. 414. 
stępstwa nie ma także znaczenia fakt, że pokrzywdzony nie rozumiał okoliczności, w których się znajdował ${ }^{13}$.

Inne transakcje dotyczące człowieka polegają w szczególności na nieodpłatnym przekazaniu go drugiej osobie lub przekazaniu go drugiej osobie w zamian za określone dobra materialne (np. mieszkanie, samochód), na zamianie jednego człowieka na drugiego, wykorzystaniu go jako przedmiotu zapłaty, potraktowaniu jako zabezpieczenia wypełnienia określonego obowiązku wynikającego $\mathrm{z}$ umowy między stronami (np. zastaw, kara), uzyskaniu określonych korzyści o charakterze osobistym lub majątkowym za przekazanie człowieka (np. zaliczenie długu), czy wypożyczeniu człowieka, tj. przekazaniu go za opłatą w czasowe posiadanie i wykorzystanie. Katalog zachowań nie jest zamknięty ${ }^{14}$.

Werbowanie stanowi „nakłonienie jednego człowieka lub kilkoro ludzi do wyrażenia zgody na wykorzystanie ich do wykonania określonych prac lub usług"15. Zatem owo zachowanie obejmuje skłonienie człowieka do wyrażenia zgody na dokonanie z jego udziałem transakcji o charakterze materialnym ${ }^{16}$. Sposoby werbowania mogą być różne: poszukiwanie kandydatów, agitacja, prowadzenie zapisów osób zainteresowanych ${ }^{17}$, obietnica, perswazja, szantaż ${ }^{18}$, nabór, najem chętnych, zastraszanie, groźby $^{19}$. Stanowią więc nie siłowe, ale psychiczne oddziaływanie na

13 M.P. Żurawliow, op. cit., s. 326.

14 L.J. Jegorowa, Priestuplienija protiw swobody, czesti $i$ dostoinstwa licznosti, [w:] Osobiennaja czast' ugołownowo kodeksa Rossijskoj Federaciji. Kommentarij. Sudiebnaja praktika. Statistika, red. W.M. Lebiediew, A.W. GaŁACHow, Moskwa 2009, s. 108.

15 O.S. Kapinus, op. cit., s. 107.

16 N.I. Priachina, Priestuplienija protiw swobody, czesti i dostoinstwa licznosti, [w:] Ugołowoje prawo Rossiji. Osobiennaja czast', red. N.M. Kropacziow, B.W. WoŁŻENkin, A.I. BojCow, Sankt Petersburg 2010, s. 287.

17 W.P. Stiepalin, op. cit., s. 266; A.B. Borisow, Kommentarij k Ugołownomu kodeksu Rossijskoj Federaciji, Moskwa 2012, s. 314.

18 N.I. Priachina, op. cit., s. 287.

19 L.A. Kopienkina, O sowierszenstwowanii st. 127-1 uk RF (torgowlia lud'mi), „Leningradskij juridiczeskij żurnal” 3/2007, s. 123; A.S. HoJAnjan, Torgowlia lud'mi $i$ ispolzowanije rabskowo truda - nowiełty ugołownowo kodeksa Rossijskoj Federacji, «Siewiero-kawkazkij juridiczeskij wiestnik» 1/2008, s. 73. 
werbowaną osobę ${ }^{20}$. Może się to odbywać w sposób jawny, jak i ukryty (np. nakłonienie do określonej pracy jako legalna siła robocza i obietnicy sprawowania patronatu ze strony określonych osób) ${ }^{21}$.

Przewożenie polega na „przemieszczeniu człowieka z jednego miejsca w drugie" 22 , zmianie jego miejsca pobytu w przestrzeni ${ }^{23}$. Obejmuje też organizację transportu ludzi zwerbowanych na potrzeby siły roboczej (załatwienie wiz, dokumentów, biletów) ${ }^{24}$. Przewóz może odbywać się dowolnym lądowym środkiem transportu ${ }^{25}$, drogą wodną lub lotniczą ${ }^{26}$, w sposób jawny i ukryty (ukrycie w środku transportu w bagażniku) ${ }^{27}$, legalnie i nielegalnie ${ }^{28}, \mathrm{z}$ użyciem przemocy lub dobrowolnie ${ }^{29}$. Dla odpowiedzialności karnej długość trasy przewozu nie ma znaczenia ${ }^{30}$. Osoba przewożąca nie jest ani kupującym, ani sprzedającym ${ }^{31}$.

Przekazywanie stanowi „przejście osoby sprzedawanej od jednego uczestnika transakcji do drugiego, który uzyskuje panowanie nad nią"32. W ten sposób następuje przekazanie prawa do człowieka na nieokreślony czas ${ }^{33}$. Dochodzi do tego poprzez „wręczenie” osoby sprzedawanej przez sprzedającego, w wyniku czego osoba sprzedawana jest nabywana

20 W.W. PaliJ, Priestuplienija protiw swobody, czesti i dostoinstwa licznosti, [w:] Kommentarij k Ugołownomu kodeksu Rossijskoj Federaciji (postatiejnyj), red. G.A. JEsakow, Moskwa 2012, s. 164.

21 M.P. Żurawliow, op. cit., s. 327.

22 O.S. Kapinus, op. cit., s. 107.

23 N.I. Priachina, op. cit., s. 287.

24 M.P. Żurawliow, op. cit., s. 327.

25 W.W. PaliJ, op. cit., s. 164.

26 M.P. ŻuraWliow, op. cit., s. 327.

27 L.J. Jegorowa, op. cit., s. 109.

28 M.P. Żurawliow, op. cit., s. 327.

29 A.S. HoJANJAN, op. cit., s. 73.

30 N.I. Wietrow, Priestuplienija protiw swobody, czesti i dostoinstwa licznosti, [w:] Ugołownoje prawo. Czast' obszczaja. Czast' osobiennaja, red. N.I. Wietrow, J.I. LiAPUNOW, Moskwa 2007, s. 314.

31 A.I. RAROG, op. cit., s. 89.

32 O.S. Kapinus, op. cit., s. 107.

33 W.J. Zanina, Torgowlia ludmi (st.1271 uk RF), «Rossijskaja justicija» 11/2007, s. 62 . 
przez kupującego. Sposób przekazania może być dowolny: darowizna, rozliczenie długu ${ }^{34}$. Jest to zachowanie pośredniczące ${ }^{35}$.

Przechowywanie obejmuje „każde zachowanie ukierunkowane na ukrycie miejsca pobytu pokrzywdzonych przed organami ścigania i innymi zainteresowanymi osobami"36. Sposoby uniemożliwiania wszelkich kontaktów ze światem ${ }^{37}$, tj. ukrycia, mogą być różne: przechowywanie w specjalnych pomieszczeniach, uniemożliwianie opuszczania określonego miejsca, ograniczanie fizycznej lub psychicznej aktywności poprzez podanie określonych środków psychoaktywnych ${ }^{38}$. Wymienione czynności dokonywane są bez woli osoby sprzedawanej ${ }^{39}$.

Przyjęcie oznacza zawładnięcie człowiekiem przez nowego „właściciela” na potrzeby jego eksploatacji ${ }^{40}$. Pojęcie eksploatacji wyjaśnia przypis 2 do art. $127^{1}$ k.k. FR. Przez eksploatację (wyzysk) człowieka rozumie się wykorzystanie go przez inne osoby do uprawiania prostytucji, jak również inne formy wyzysku seksualnego, pracę niewolniczą, stan poddańczej zależności.

Niektórzy uważają, że tylko kupno-sprzedaż stanowi handel w dosłownym znaczeniu, a pozostałe zachowania mają charakter wspomagający. „Mogą stanowić oddzielne elementy przestępczego handlu ludźmi"41.

Przestępstwo to zagrożone jest karą robót przymusowych na okres do pięciu lat lub karą pozbawienia wolności na okres do lat sześciu.

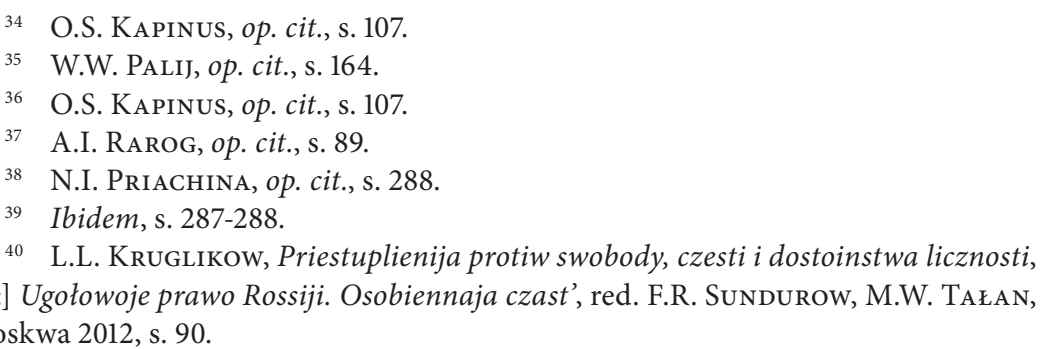
Moskwa 2012, s. 90.

${ }^{41}$ A.I. RAROG, op. cit., s. 88. 
3. TYP KWALIFIKOWANY HANDLU LUDŹMI - ART. $127^{1}$ PKT 2 K.K. FR

Na podstawie art. $127^{1}$ pkt 2 k.k. FR karalny jest handel ludźmi dokonany:

a. w stosunku do dwóch lub więcej osób;

b. w stosunku do osoby nieletniej;

c. przez osobę, wykorzystującą swoje stanowisko służbowe;

d. z przewiezieniem pokrzywdzonego przez granicę państwową Federacji Rosyjskiej lub z nielegalnym przetrzymywaniem go za granicą;

e. Z wykorzystaniem podrobionych dokumentów, jak również z odebraniem, ukryciem, zniszczeniem dokumentów, poświadczających tożsamość pokrzywdzonego;

f. z zastosowaniem przemocy lub z groźbą jej zastosowania;

g. w celu pozyskania od pokrzywdzonego organów lub tkanek;

h. w stosunku do osoby, co do której sprawca wcześniej wiedział, że znajduje się w stanie bezradności lub jest materialnie bądź w inny sposób zależna od sprawcy;

i. w stosunku do kobiety, co do której sprawca wcześniej wiedział, że jest w ciąży.

Formy zachowania sprawcy, stanowiące realizację strony przedmiotowej przepisu, zostaną scharakteryzowane poniżej.

Handel ludźmi wobec co najmniej dwóch osób wymaga dokonania tego równocześnie lub w niedługim okresie. Jest objęty jednym zamiarem $^{42}$.

Przestępstwo to w stosunku do osoby nieletniej wymaga od sprawcy świadomości i wiedzy o wieku pokrzywdzonego ${ }^{43}$. Musi on wiedzieć, że pokrzywdzony nie osiągnął 18. roku życia ${ }^{44}$. Mógł on oceniać wiek pokrzywdzonego na podstawie jego słów, fizycznego i psychicznego rozwoju, sugerując się słowami innych osób, jednakże jego błędne oceny nie mają znaczenia dla odpowiedzialności ${ }^{45}$.

N.I. Priachina, op. cit., s. 290.

Ibidem, s. 290.

W.P. STIEPALIN, op. cit., s. 267.

W.W. SWIERCZKow, op. cit., s. 416. 
Handel ludźmi dokonany przez osobę wykorzystującą swoje stanowisko służbowe wymaga wykorzystania przez nią swoich uprawnień lub obowiązków wykonywanych w ramach zatrudnienia w państwowych lub prywatnych organizacjach lub organach ${ }^{46}$. Sprawcami tego przestępstwa mogą być na przykład pracownicy opieki socjalnej, domu dziecka $^{47}$, służby zdrowia, policjanci, celnicy ${ }^{48}$.

Przestępstwo to polegające na przewiezieniu pokrzywdzonego przez granicę państwową Federacji Rosyjskiej wymaga przeprowadzenia transakcji kupna-sprzedaży nie tylko w kraju, lecz także i za granicą ${ }^{49}$. Oznacza to zarówno jawne lub ukryte ${ }^{50}$, jak i legalne lub nielegalne przekroczenie granicy ${ }^{51}$. Może odbyć się pod pozorem turystycznej lub służbowej podróży ${ }^{52}$. Kierunek przewozu może być różny: $z$ terytorium Rosji na obszar innego państwa, z terytorium państwa obcego do Rosji, tranzyt przez Rosję do innego kraju ${ }^{53}$. Dla odpowiedzialności sprawcy zgoda pokrzywdzonego na wywóz z kraju nie ma znaczenia ${ }^{54}$. Z kolei nielegalne przetrzymywanie pokrzywdzonego za granicą oznacza pozbawienie go możliwości powrotu do kraju lub nawiązania kontaktu $\mathrm{z}$ rosyjskimi dyplomatami ${ }^{55}$. Stanowi retencję wbrew jego woli na terytorium innego państwa ${ }^{56}$.

Handel ludźmi dokonany z wykorzystaniem podrobionych dokumentów, jak również z odebraniem, ukryciem, zniszczeniem dokumentów poświadczających tożsamość pokrzywdzonego dotyczy zachowań

46 W.W. PaliJ, op. cit., s. 165.

47 M.P. Żurawliow, op. cit., s. 328.

48 W.W. SWIERCZKow, op. cit., s. 416.

49 N.I. Priachina, op. cit., s. 292.

50 W.W. SWIERCZKow, op. cit., s. 416.

51 W.W. Palij, op. cit., s. 165.

52 W.W. SWierczkow, op. cit., s. 417.

53 Ibidem, s. 416-417.

54 M.P. Żurawliow, op. cit., s. 328.

55 N.G. Kadnikow, Priestuplienija protiw licznosti, [w:] Kommentarij k Ugołownomu kodeksu Rossijskoj Federaciji, red. S.W. DJakow, N.G. KaDNiKow, Moskwa 2016, s. 284.

56 W.W. Palij, op. cit., s. 165. 
z użyciem dokumentów tożsamości (np. paszport, świadectwo urodzenia $^{57}$ ). Polegają one na przykład na wykorzystywaniu dokumentów zawierających zniekształcone, nieprawdziwe informacje między innymi o dacie, miejscu urodzenia; na odebraniu dokumentów poprzez siłowe zabranie, pozbawieniu dokumentów w celu doprowadzenia do zależności; na ukryciu dokumentów poprzez przechowywanie ich w taki sposób, by pokrzywdzony nie mógł ich odnaleźć ${ }^{58}$. Zachowanie sprawcy polega też na fizycznym zniszczeniu autentycznych dokumentów, uniemożliwiając w ten sposób identyfikację ${ }^{59}$, uczynieniu ich bezwartościowymi poprzez fizyczną eliminację (np. spalenie) ${ }^{60}$.

Przestępstwo to dokonane z użyciem przemocy lub z groźbą jej użycia wymaga dokonania pobicia, spowodowania lekkich lub średnich uszkodzeń ciała, a także groźby użycia przemocy powodującej ciężkie uszkodzenie ciała ${ }^{61}$. Obejmuje groźne dla zdrowia następstwa (spowodowanie lekkiego i średniego uszkodzenia ciała), jak i mniej groźne (pozbawienie wolności, związywanie, powodowanie bólu fizycznego). Groźbę użycia wyrażoną na zewnątrz należy traktować jako zamiar wywołania poważnych następstw ${ }^{62}$.

Handel ludźmi dokonany w celu pozyskania od pokrzywdzonego organów lub tkanek wymaga nie tylko działania w celu transplantacji, lecz dotyczy także doświadczeń i eksperymentów naukowych, obrzędów rytualnych ${ }^{63}$. Pokrzywdzony będzie dawcą tkanek ${ }^{64}$. Dla odpowiedzialności karnej sprawcy nie ma znaczenia, czy transplantacja doszła do skutku ${ }^{65}$.

Przestępstwo to dokonane w stosunku do osoby, co do której sprawca wcześniej wiedział, że znajduje się w stanie bezradności lub

W.W. SWIERCZKow, op. cit., s. 417.

L.J. JEgorowa, op. cit., s. 111.

W.P. Stiepalin, op. cit., s. 267-268.

L.J. Jegorowa, op. cit., s. 111-112.

N.I. Priachina, op. cit., s. 292.

W.W. PaliJ, op. cit., s. 165.

N.I. Priachina, op. cit., s. 293.

W.P. Stiepalin, op. cit., s. 268.

M.P. Żurawliow, op. cit., s. 328.
} 
jest materialnie bądź w inny sposób zależna od sprawcy, wymaga wiedzy sprawcy na temat sytuacji pokrzywdzonego. Podobnie, handel ludźmi w stosunku do kobiety, co do której sprawca wcześniej wiedział, że jest się w ciąży, wymaga jego wiedzy na temat osobistej sytuacji pokrzywdzonej ${ }^{66}$. Obie czynności polegają na całkowitej lub częściowej zależności pokrzywdzonego od sprawcy lub opartej na relacjach rodzinnych, małżeńskich, będących wynikiem umowy ${ }^{67}$. Wymienione czynności powodują pewien zakres zależności od sprawcy, któremu pokrzywdzony nie jest w stanie się temu przeciwstawić. Jest bezradny ${ }^{68}$.

Przestępstwo to zagrożone jest karą pozbawienia wolności na okres od trzech do dziesięciu lat $\mathrm{z}$ pozbawieniem prawa do zajmowania określonych stanowisk lub prowadzenia określonego rodzaju działalności na okres do piętnastu lat, bądź bez zastosowania tej sankcji i z ograniczeniem wolności na okres do dwóch lat bądź bez zastosowania tej sankcji.

Przypis 1 do art. $127^{1}$ k.k. przewiduje specjalny rodzaj uwolnienia od odpowiedzialności - czynny żal. Wynika z niego, że skorzystać z tej instytucji może osoba, która po raz pierwszy dokonała przestępstwa $\mathrm{z}$ art. $127^{1}$ k.k. lub z art. $127^{1}$ pkt 2 ust. a k.k. Ponadto, dobrowolnie uwolniła poszkodowanego i przyczyniła się do ujawnienia dokonanego przestępstwa. Nie ponosi odpowiedzialności, pod warunkiem że jej działania nie wypełniają znamion innych przestępstw. Instytucję tę ocenia się niejednoznacznie, zarzucając unikanie odpowiedzialności mimo osiągnięcia swoich celów, brak określenia okresu do uwolnienia pokrzywdzonego ${ }^{69}$. Stanowi to pewien kompromis z przestępcami w celu uratowania pokrzywdzonego ${ }^{70}$.

66 N.I. Priachina, op. cit., s. 293.

67 W.P. Stiepalin, op. cit., s. 268.

68 T.W. Dołgolienko, Priestuplienija protiw swobody, czesti i dostoinstwa licznosti, [w:] Ugołownoje prawo. Osobiennaja czast', red. I.W. SzIszko, Moskwa 2012, s. 95.

69 N.I. Priachina, op. cit., s. 293.

70 R.W. Zaкомоєdin, Priestuplienija protiw swobody, czesti i dostoinstwa licznosti, [w:] Ugołowoje prawo Rossiji. Obszczaja i osobiennaja czasti, red. W.K. DuJunow, Moskwa 2017, s. 347. 
4. TYP SZCZEGÓLNIE KWALIFIKOWANY ${ }^{71}$ HANDLU LUDŹMI ART. $127^{1}$ PKT 3 K.K. FR

Typ szczególnie kwalifikowany handlu ludźmi zawarto w art. $127^{1}$ pkt 3 k.k. FR. Przyjęto, że strona przedmiotowa przestępstwa obejmuje czyny, przewidziane $\mathrm{w}$ art. $127^{1}$ pkt 1 i art. $127^{1}$ pkt 2:

a. których następstwem była, spowodowana nieostrożnością, śmierć, spowodowanie ciężkiego uszczerbku na zdrowiu poszkodowanego lub inne ciężkie następstwa;

b. dokonane w sposób niebezpieczny dla życia i zdrowia wielu ludzi;

c. dokonane przez grupę zorganizowaną.

W tym miejscu pokrótce zostaną scharakteryzowane powyżej wymienione znamiona.

W wypadku handlu ludźmi, w którym następstwem była, spowodowana nieostrożnością, śmierć, spowodowanie ciężkiego uszczerbku na zdrowiu poszkodowanego lub inne ciężkie następstwa, musi zaistnieć związek przyczynowo-skutkowy między handlem ludźmi i spowodowaniem śmierci lub wymienionych obrażeń ${ }^{72}$. Skutki powinny być rezultatem samobójstwa, niewłaściwych warunków przetrzymywania lub trudnych warunków pracy niewolniczej ${ }^{73}$. Inne ciężkie następstwa powinny obejmować zarażenie wirusem HIV, wywołanie znacznej szkody materialnej ${ }^{74}$.

Dokonanie tego przestępstwa w sposób niebezpieczny dla życia i zdrowia wielu ludzi powinno polegać na stworzeniu niebezpieczeństwa dla minimum dwóch osób ${ }^{75}$, na przykład poprzez przewóz lub ukrywanie pokrzywdzonych w warunkach stwarzających ryzyko dla

${ }^{71}$ Typ szczególnie kwalifikowany przestępstwa (brzmienie wynikające z tłumaczenia z jęz. rosyjskiego) oznacza czyn zawierający okoliczności o znacznie większym stopniu społecznego niebezpieczeństwa niż typ kwalifikowany. Zagrożony jest on surowszą karą.

72 N.I. Priachina, op. cit., s. 293.

73 M.P. Żurawliow, op. cit., s. 329.

74 W.W. SWIERCZKow, op. cit., s. 418.

75 N.I. Priachina, op. cit., s. 293. 
życia lub zdrowia ${ }^{76}$. Może ono nastąpić na etapie przewozu lub ukrywania pokrzywdzonego ${ }^{77}$.

Przestępstwo to dokonane przez grupę zorganizowaną polega na popełnieniu go przez stałą grupę osób, uprzednio powstałą w celu popełniania przestępstwa lub przestępstw ${ }^{78}$.

Przestępstwo to zagrożone jest karą pozbawienia wolności na okres od ośmiu do piętnastu lat z ograniczeniem wolności na okres do dwóch lat bądź bez zastosowania tej sankcji.

\section{Pozostąe Znamiona PRZEstęPstwa handLU LUdŹmi}

Przedmiot przestępstwa handlu ludźmi stanowi wolność osobista człowieka. Oznacza ona wolność w kilku sferach: w sferze fizycznej jako swobodne przemieszczanie się, wybór dowolnego miejsca pobytu; w sferze wolności woli jako brak zewnętrznych oddziaływań (przymusu); a w sferze wolności wyboru jako swobodny wybór określonych zachowań $^{79}$. Inni uważają, że przedmiot stanowią także stosunki społeczne i prawo do osobistego rozporządzania sobą, tj. swoimi przyrodzonymi prawami $^{80}$. W typie kwalifikowanym i szczególnie kwalifikowanym przestępstwa stanowi go też życie i zdrowie pokrzywdzonego ${ }^{81}$.

Należy przy tym podkreślić, że pokrzywdzonym może być osoba płci żeńskiej i męskiej, niezależnie od wieku ${ }^{82}$. Zatem cechy społeczno-demograficzne człowieka, takie jak: wiek, płeć, sytuacja materialna jako

76 M.P. Żurawliow, op. cit., s. 329.

77 N.I. Priachina, op. cit.,s. 293.

78 Ibidem, s. 293.

79 G.W. Owczinnikow, Prawowyje aspiekty protiwodiejstwija torgowlie lud'mi, [w:] Gosudarstwiennaja granica, organizowannaja priestupnost, zakon i bezopasnost Rossiji, red. A.I. DoŁgowa, Moskwa 2006, s. 97.

80 L.J. JegorowA, op. cit., s. 108.

81 J.S. Byszewskaja, Torgowlia ludmi kak odno iż priestuplienij sowriemiennosti, [w:] Trudy juridiczeskowo fakultieta siewiero-kawkazkowo gosudarstwiennowo techniczeskowo uniwersiteta, Wypusk 8, Stawropol 2005, s. 144.

82 F.R Sundurow, M.W. TaŁan, Ugołowoje prawo Rossiji. Osobiennaja czast', Moskwa 2012, s. 89. 
pokrzywdzonego nie mają znaczenia dla odpowiedzialności sprawcy ${ }^{83}$. Podobnie, nie ma znaczenia zgoda pokrzywdzonego ${ }^{84}$. Ze względu na możliwość kupna-sprzedaży jednego człowieka niektórzy zgłaszają zastrzeżenia do nazwy przestępstwa „handel ludźmi”, co oznacza, że ich zdaniem nie dotyczy ono pojedynczego człowieka ${ }^{85}$.

Podmiot przestępstwa stanowi osoba, która ukończyła 16 lat. Mogą nimi być rodzice, opiekunowie, bliscy, nieznajomi ${ }^{86}$.

Strona podmiotowa handlu ludźmi polega na umyślności, a werbowanie, przewożenie, przekazywanie, przechowywanie lub przyjęcie wymaga nastąpienia celu eksploatacji człowieka. Sprawca rozumie, że zajmuje się handlem ludźmi i chce dokonać tego czynu. Zachowuje się $\mathrm{z}$ pełną świadomością ${ }^{87}$.

Przestępstwo $\mathrm{z}$ art. $127^{1}$ pkt 1 ma charakter formalny. Przestępstwo uznaje się za dokonane $\mathrm{w}$ chwili dokonania jednego $\mathrm{z}$ wymienionych zachowań ${ }^{88}$, a przestępstwo $\mathrm{z}$ art. $127^{1}$ pkt 2-3 ma charakter materialno-formalny ${ }^{89}$.

Przestępstwo to często wykazuje związki z innymi przestępstwami: porwanie człowieka (art. 126), wzięcie zakładnika (art. 206), przestępstwa przeciwko cielesnej nietykalności człowieka i swobody seksualnej człowieka (art. 131-135).

Podsumowując, przedstawiony zakres regulacji został zasadniczo implementowany z przepisów międzynarodowych dotyczących handlu ludźmi. Uwagę zwraca jego zbytnia kazuistyka (wyodrębnienie zachowań sprawcy w sposób bardzo szczegółowy) oraz wyszczególnienie

83 M.A. Kaufman, Priestuplienija protiw swobody, czesti i dostoinstwa licznosti, [w:] Ugołowoje prawo Rossiji. Czasti obszczaja i osobiennaja, red. A.W. BrILliantow, Moskwa 2015, s. 372.

${ }^{84}$ L.W. Inogamowa-HeŁaJ, Art. 127¹, [w:] Kommentarij k Ugołownomu kodeksu Rossijskoj Federaciji, red. A.I. Czuczajew, Moskwa 2005, s. 296.

85 O.W. Szliapnikowa, J.J. Szalimow, Ugołowno-prawowyje aspiekty torgowli lud'mi, [w:] Kriminalnaja ekonomika i organizowannaja priestupnost', red. A.I. DoŁGOWA, Moskwa 2007, s. 108.

86 N.I. Priachina, op. cit., s. 289.

87 Ibidem, s. 289.

88 W.W. PaliJ, op. cit., s. 164.

89 W.W. SWIERCZKow, op. cit., s. 414. 
trzech typów przestępstwa (podstawowy, kwalifikowany i szczególnie kwalifikowany). Doprowadziło to do wprowadzenia za te czyny surowych kar (znacznie wyższych i bardziej rozbudowanych rodzajowo niż w Polsce) za popełnienie przestępstwa handlu ludźmi. Można stwierdzić, że stało się to zgodnie $\mathrm{z}$ dominującą tendencją cechującą rosyjski kodeks karny, przejawiającą się w surowości prawa i jego szczegółowości. Pomimo tych modyfikacji należy pozytywnie odnieść się do obowiązującej regulacji prawnej. Jednakże, jak zauważają niektórzy: „Znaczenia środków karnoprawnych obowiązujących w Rosji w zakresie zwalczania handlu ludźmi nie należy przeceniać. Poważnych pozytywnych osiągnięć $\mathrm{w}$ rozwiązaniu tego problemu nie można oczekiwać bez poprawy poziomu życia w kraju i poprawy sytuacji w zakresie bezrobocia wśród młodzieży"90.

PRZESTĘPSTWO HANDLu LUdŹMi W RosJi - ASPEKTY PRAWNE

\section{Streszczenie}

Opracowanie zawiera omówienie prawnej regulacji przestępstwa handlu ludźmi w Federacji Rosyjskiej. Zwrócono w nim uwagę na fakt niedługiego okresu obowiązywania przepisu dotyczącego tego czynu w rosyjskim kodeksie karnym z 1996 r., jak również na gwarancje ochrony człowieka przed nim występujące w rosyjskiej konstytucji z 1993 r. Zagadnienie zostało omówione według ustawowych znamion przestępstwa. Wiele uwagi poświęcono analizie rozbudowanej strony przedmiotowej, występującej w typie podstawowym, kwalifikowanym i szczególnie kwalifikowanym. W rozważaniach podkreślono widoczną kazuistykę przyjętego rozwiązania i zagrożenie przestępstwa surowymi sankcjami. Wskazano na niektóre odrębności w stosunku do polskiej regulacji.

90 I.A. KlipickiJ, G.P. MieŁKonjan, Torgowlia lud'mi: zakonodatielstwo i sudiebnaja praktika, „Rossijskaja justicija” 12/2006, s. 40. 
Human Trafficking in Russia: Legal Aspects

\section{Summary}

The study provides an overview of the legal regulation on human trafficking in the Russian Federation. It observes that the provision for this offence in the Russian Penal Code of 1996, as well as the guarantees of protection against human trafficking in the Russian Constitution of 1993 were in force only for a short time. The issue is discussed on the basis of the statutory features of this criminal offence, with considerable attention to the analysis of the extended objective side of the offence in its basic, qualified, and particularly qualified types. The study focuses on the evident casuistry in the arrangement which was adopted and the severe penalties laid down for this crime. The author also points out some of the differences between the Russian provisions and the Polish regulations.

Słowa kluczowe: „żywy towar”; kupno-sprzedaż człowieka; handel ludźmi.

Keywords: humans for sale; buying and selling a human being; human trafficking.

\section{Literatura}

Borisow A.B., Kommentarij k Ugołownomu kodeksu Rossijskoj Federaciji, Moskwa 2012, s. 304-322.

Byszewskaja J.S., Torgowlia ludmi kak odno iż priestuplienij sowriemiennosti, [w:] Trudy juridiczeskowo fakultieta siewiero-kawkazkowo gosudarstwiennowo techniczeskowo uniwersiteta, Wypusk 8, Stawropol 2005, s. 143-149.

DoŁgolienko T.W., Priestuplienija protiw swobody, czesti i dostoinstwa licznosti, [w:] Ugołownoje prawo. Osobiennaja czast', red. I.W. SzIszko, Moskwa 2012, s. 95-99.

Federalnyj zakon ot 13 ijunia 1996 g. Nr 63 FZ „Ugołownyj kodeks Rossijskoj Federaciji”, http://www.consultant.ru/document/cons_doc_LAW_10699/ (dostęp: 21.10.2018 r.). 
Federalnyj zakon ot 8 dekabria 2003 g. Nr 162 „O wniesienii izmienienij i dopołnienij w Ugołownyj kodeks Rossijskoj Federaciji”, http://base.garant. ru/12133485/ (dostęp: 21.10.2018 r.).

Hojanjan A.S., Torgowlia lud'mi $i$ ispolzowanije rabskowo truda - nowiełty ugołownowo kodeksa Rossijskoj Federacji, «Siewiero-kawkazkij juridiczeskij wiestnik» 1/2008, s. 71-78.

Inogamowa-HeŁaj L.W., Art. 1271, [w:] Kommentarij k Ugołownomu kodeksu Rossijskoj Federaciji, red. A.I. Czuczajew, Moskwa 2005, s. 290-304.

Jegorowa L.J., Priestuplienija protiw swobody, czesti i dostoinstwa licznosti, [w:] Osobiennaja czast' ugołownowo kodeksa Rossijskoj Federaciji. Kommentarij. Sudiebnaja praktika. Statistika, red. W.M. Lebiediew, A.W. GAŁACHOW, Moskwa 2009, s. 107-113.

Kadnikow N.G., Priestuplienija protiw licznosti, [w:] Kommentarij k Ugołownomu kodeksu Rossijskoj Federaciji, red. S.W. DJakow, N.G. Kadnikow, Moskwa 2016, s. 278-292.

Kapinus O.S., Priestuplienija protiw swobody, czesti i dostoinstwa licznosti, [w:] Ugołownoje prawo Rossiji. Osobiennaja czast', red. I.E. ZwIERCZAKowSKIJ, Moskwa 2010, s. 106-110.

Kaufman M.A., Priestuplienija protiw swobody, czesti i dostoinstwa licznosti, [w:] Ugołowoje prawo Rossiji. Czasti obszczaja i osobiennaja, red. A.W. BRILLIANTOW, Moskwa 2015, s. 366-379.

Kazakowa W.A., Michlin A.S., Art. 1271, [w:] Kommentarij k Ugołownomu kodeksu Rossijskoj Federaciji, red. W.I. Radczenko, Moskwa 2009, s. 200-210.

Klipickij I.A., MieŁkonjan G.P., Torgowlia lud'mi: zakonodatielstwo i sudiebnaja praktika, «Rossijskaja justicija»12/2006, s. 39-41.

Konstitucija Rossijskoj Federaciji ot 12 dekabria 1993 g., http://www.constitution.ru/ (dostęp: 21.10 .2018 r.).

Kopienkina L.A., O sowierszenstwowanii st. 127-1 uk RF (torgowlia lud'mi), «Leningradskij juridiczeskij żurnal»3/2007, s. 121-127.

Kruglikow L.L., Priestuplienija protiw swobody, czesti i dostoinstwa licznosti, [w:] Ugołowoje prawo Rossiji. Osobiennaja czast', red. F.R. Sundurow, M.W. TA£an, Moskwa 2012, s. 84-97.

OwCZInnikow G.W., Prawowyje aspiekty protiwodiejstwija torgowlie lud'mi, [w:] Gosudarstwiennaja granica, organizowannaja priestupnost, zakon i bezopasnost Rossiji, red. A.I. DoŁgowa, Moskwa 2006, s. 94-102.

Palij W.W., Priestuplienija protiw swobody, czesti i dostoinstwa licznosti, [w:] Kommentarij k Ugołownomu kodeksu Rossijskoj Federaciji (postatiejnyj), red. G.A. JesAKow, Moskwa 2012, s. 163-165. 
Priachina N.I., Priestuplienija protiw swobody, czesti i dostoinstwa licznosti, [w:] Ugołowoje prawo Rossiji. Osobiennaja czast', red. N.M. Kropacziow, B.W. Wołżenkin, A.I. Bojcow, Sankt Petersburg 2010, s. 286-294.

Rarog A.I., Priestuplienija protiw swobody, czesti i dostoinstwa licznosti, [w:] Ugołowoje prawo Rossiji. Osobiennaja czast', red. A.I. Rarog, Moskwa 2009, s. 87-92.

Stiepalin W.P., Priestuplienija protiw swobody, czesti i dostoinstwa licznosti, [w:] Kommentarij k Ugołownomu kodeksu Rossijskoj Federaciji, red. A.I. RAROG, Moskwa 2012, s. 265-269.

Sundurow F.R, Tałan M.W., Ugołowoje prawo Rossiji. Osobiennaja czast', Moskwa 2012, s. 82-97.

Swierczkow W.W., Priestuplienija protiw swobody, czesti i dostoinstwa licznosti, [w:] Kommentarij k Ugołownomu kodeksu Rossijskoj Federaciji, red. W.T. Tomin, W.W. Swierczkow, Moskwa 2010, s. 412-418.

Szliapnikowa O.W., Szalimow J.J., Ugołowno-prawowyje aspiekty torgowli lud'mi, [w:] Kriminalnaja ekonomika i organizowannaja priestupnost', red. A.I. DoŁgowa, Moskwa 2007, s. 108-111.

Wietrow N.I., Priestuplienija protiw swobody, czesti i dostoinstwa licznosti, [w:] Ugołownoje prawo. Czast'obszczaja. Czast' osobiennaja, red. N.I. WiETrow, J.I. Liapunow, Moskwa 2007, s. 309-318.

ZaкомоŁdin R.W., Priestuplienija protiw swobody, czesti i dostoinstwa licznosti, [w:] Ugołowoje prawo Rossiji. Obszczaja i osobiennaja czasti, red. W.K. DuJunow, Moskwa 2017, s. 342-350.

Żurawliow M.P., Priestuplienija protiw swobody, czesti i dostoinstwa licznosti, [w:] Ugołowoje prawo Rossiji. Czasti obszczaja i osobiennaja, red. A.I. Rarog, Moskwa 2010, s. 326-331. 